Swarthmore College

Works

3-1-1994

Natural History Of Schistosoma Mansoni Infection In Mice: Egg Production, Egg Passage In The Feces, And Contribution Of Host And Parasite Death To Changes In Worm Numbers

A. W. Cheever , '82

J. E. Mosimann

S. Deb

Erik Allen Cheever , '82

Swarthmore College, erik_cheever@swarthmore.edu

R. H. Duvall

Follow this and additional works at: https://works.swarthmore.edu/fac-engineering

Part of the Engineering Commons

Let us know how access to these works benefits you

Recommended Citation

A. W. Cheever , '82; J. E. Mosimann; S. Deb; Erik Allen Cheever , '82; and R. H. Duvall. (1994). "Natural History Of Schistosoma Mansoni Infection In Mice: Egg Production, Egg Passage In The Feces, And Contribution Of Host And Parasite Death To Changes In Worm Numbers". American Journal Of Tropical Medicine And Hygiene. Volume 50, Issue 3. 269-280.

https://works.swarthmore.edu/fac-engineering/36

This work is brought to you for free by Swarthmore College Libraries' Works. It has been accepted for inclusion in Engineering Faculty Works by an authorized administrator of Works. For more information, please contact myworks@swarthmore.edu. 


\title{
NATURAL HISTORY OF SCHISTOSOMA MANSONI INFECTION IN MICE: EGG PRODUCTION, EGG PASSAGE IN THE FECES, AND CONTRIBUTION OF HOST AND PARASITE DEATH TO CHANGES IN WORM NUMBERS
}

\author{
ALLEN W. CHEEVER, JAMES E. MOSIMANN, SUBRATO DEB, \\ ERIK A. CHEEVER, AND RODNEY H. DUVALL \\ Laboratory of Parasitic Diseases, National Institute of Allergy and Infectious Diseases, \\ National Institutes of Health, Bethesda, Maryland; Department of Engineering, Swarthmore \\ College, Swarthmore, Pennsylvania
}

\begin{abstract}
Mice, C57B1/6N (B6) and BALB/cAnN (BALB), infected with Schistosoma mansoni were examined 8-26 weeks postinfection (PI) to estimate the fecundity of the worms and the contribution of death of worms and the death of heavily infected mice to the decrease in worm numbers in chronic infections. Portal worms were recovered by perfusion and the lungs were examined for parasites shunted from the portal circulation. Animals that died were more heavily infected than those that survived. Between eight and 12 weeks PI, this loss of worms resulted in a net decrease of approximately $19 \%$ of worm pairs in surviving BALB mice, but of only $4 \%$ in B6 mice. Loss of portal worms to the lungs after the eighth week of infection was $9-13 \%$ of portal worms in BALB mice and $3-4 \%$ in B6 mice. The estimated rates of egg production by $S$. mansoni decreased slightly with time in both strains of mice. At 12 and 20 weeks PI, tissue eggs per worm pair and eggs passed in the feces per worm pair often decreased as the intensity of infection increased. We do not consider the loss of worms in the murine host relevant to most infections in humans because of the high intensity of infection relative to body size in mice and the high frequency of severe portal obstruction in murine infections.
\end{abstract}

Schistosome infections in experimental animals are less complex, or at least more readily studied, than infections in humans. We were interested in examining several features of Schistosoma mansoni infections in mice quantitatively in short-term and long-term infections. We wished to examine the rates of schistosome egg laying in mice at different intervals after infection and to correlate these with the rate of passage of eggs in the feces.

The longevity of $S$. mansoni in the murine host has also not been properly examined. It is relevant, however, because death of worms in mice has not been demonstrated in murine infections used as models to study the epidemiology of $S$. mansoni infections in humans.' On the other hand, mice exposed to large numbers of $S$. mansoni cercariae die earlier than those exposed to fewer cercariae, and we presumed that earlier death of the most heavily infected animals would result in lower worm numbers in mice that survived ${ }^{24}$ Therefore, we considered it important to examine quantitatively the relative contribution of death of worms and death of infected mice to decreasing worm burdens in long-term as compared with short-term infections.

We determined worm numbers and the site of worm death in $\mathrm{C} 57 \mathrm{Bl} / 6 \mathrm{~N}$ (B6) and $\mathrm{BALB} / \mathrm{cAnN}$ (BALB) mice exposed to widely varying numbers of S. mansoni cercariae 8-26 weeks previously. We also examined the passage of eggs in the feces, the accumulation of eggs in the tissues, and hepatic and pulmonary pathology in these mice and the relation of these variables to infection intensity.

\section{MATERIAIS AND METHODS}

\section{Mice and schistosomes}

Both B6 and BALB mice were obtained from the Division of Cancer Treatment (Frederick, MD) or bred from stock provided by that facility. Cercariae of a Puerto Rican (NMRI) ${ }^{5}$ strain of $S$. mansoni were provided by Dr. Fred Lewis (Biomedical Research Institute, Rockville, MD). Mice were infected by subcutaneous injection of cercariae as follows.

Experiment 1. Sixty male or female seven- 
week-old B6 mice and 120 male 5-10-week-old BALB mice were exposed to 50 cercariae each by subcutaneous injection. The $\mathrm{B} 6$ mice were killed 21 weeks after infection and the BALB mice were killed 16,20 , or 26 weeks after exposure. The B6 mice were exposed on a single occasion but BALB mice were exposed in small groups at different times.

Experiment 2. Female 12-16-week-old mice were exposed to 40,80 , or 120 cercariae by subcutaneous injection. A total of $120 \mathrm{~B} 6$ and 120 BALB mice were exposed and 20 uninfected mice of each strain were also examined.

\section{Parasitologic examination}

Feces were collected and examined as previously described. ${ }^{6}$ If no eggs were found in four aliquots (approximately $20 \mathrm{mg}$ of feces), as occurred in $5 \%$ of the animals, then calculations assumed that 0.5 eggs were present in the volume examined. Mice were killed the next day and examined as indicated below.

Worms were recovered from the portal venous system by a modification of the method of Duvall and DeWitt. ${ }^{7}$ Preliminary examination had shown adult worms in periesophageal variceal veins, in the right heart, and in pulmonary arterial branches in the lungs. In the first experiment, we examined the possibility that some worms were forced into the pulmonary circulation during perfusion. Mice were killed by the intraperitoneal injection of $12 \mathrm{mg}$ of pentobarbital containing 20 units of heparin and the vena cava and periesophageal veins were ligated just above the diaphragm before perfusion. The lungs in half of the mice were inflated by intratracheal injection of formalin and used for routine histologic sections. In the remaining mice, the lungs were crushed between glass plates to look for worms and the lungs were then digested for counting of eggs, except for minute areas containing worms that were examined histologically (data not shown). No difference in the number of worms in the lungs was found with or without ligation of the veins. Mice were given heparin intraperitoneally but were killed by cervical dislocation in the second experiment to avoid movement of the worms out of the portal system after administration of pentobarbital, ${ }^{7}$ and ligatures were placed as above. Pentobarbital, $2 \mathrm{mg} / \mathrm{ml}$, was added to the perfusion fluid to facilitate recovery of the worms. The lungs were crushed in all these mice and then digested in half of the mice and examined histologically in the other half. The number of eggs in lungs not digested was taken to be the mean of eggs in the lungs of the group, by mouse strain, exposed to the same number of cercariae and killed at the same time.

The exact number of worms in lung lesions was sometimes uncertain and in such cases we estimated the minimum number that we thought were present. Some worms were obviously dead when examined in crushed lung, but we estimated the proportion of live and dead worms from microscopic sections. It was often difficult to determine the gender of dead worms and we have not attempted to derive separate totals for male and female worms in the lungs.

For each mouse, approximately half of the liver was fixed for routine histologic examination. A $200 \mathrm{mg}$ portion of the liver, generally from the largest (left) lobe, was used for determination of collagen content. The remainder of the liver was crushed between glass slides and examined under a dissecting microscope to detect dead worms. The crushed liver and the gut were digested overnight at $37^{\circ} \mathrm{C}$ in 10 volumes of $4 \%$ $\mathrm{KOH}$, diluted to between 100 and $500 \mathrm{ml}$, and the schistosome eggs counted in two aliquots of one milliliter in Sedgwick-Rafter chambers (Ace Scientific, Rockville, MD). ${ }^{6}$ The number of eggs in the liver was calculated after correcting for the portion of liver not digested.

\section{Pathology}

The volumes of granulomas around single mature eggs or groups of 3-5 eggs were calculated from measurement of the granuloma diameters made from histologic sections using an ocular micrometer. For determination of collagen content, $200 \mathrm{mg}$ of liver was digested in $6 \mathrm{~N}$ $\mathrm{HCl}$ at $110^{\circ} \mathrm{C}$ for $18 \mathrm{hr}$. Humin pigments were removed $^{8}$ and a portion of the digest was neutralized with $\mathrm{NaOH}$. Collagen was measured as hydroxyproline using technique $\mathrm{B}$ of Bergman and Loxley ${ }^{9}$ and is expressed as micromoles per liver (or per 10,000 eggs or per worm pair) after subtracting the hydroxyproline content of normal liver.

\section{Examination of dead mice}

All mice that died were examined. A gross inspection of the viscera was made to determine 
the cause of death. The entire liver was digested in $\mathrm{KOH}$ to count the eggs present. The number of worm pairs likely to have been present was estimated from the number of liver eggs per worm pair in mice that had been killed. The calculation took into account the lesser proportion of eggs present in the liver of more heavily infected mice. ${ }^{10}$ The transition between the eight-, 12-, and 20-week timepoints was assumed to be linear.

\section{Calculation of egg production by the worms}

The rate of accumulation of eggs per worm pair in the tissues was determined by subtracting tissue eggs per worm pair at eight weeks from the value at 12 weeks for the first time period and the 12-week value from the 20 -week figure for the second time period. Eggs per worm pair in the feces were taken as the mean of the eightand 12-week values for the first time period and the mean of the 12- and 20-week values for the second time period.

\section{Statistical analysis}

The relationship of infection intensity to the various parameters studied was examined using $\log$ - $\log$ regressions because use of logarithms gives a more homogeneous variance. For variables that were dependent on infection intensity, groups were compared by analysis of covariance using logarithms of the variable and of the covariate.

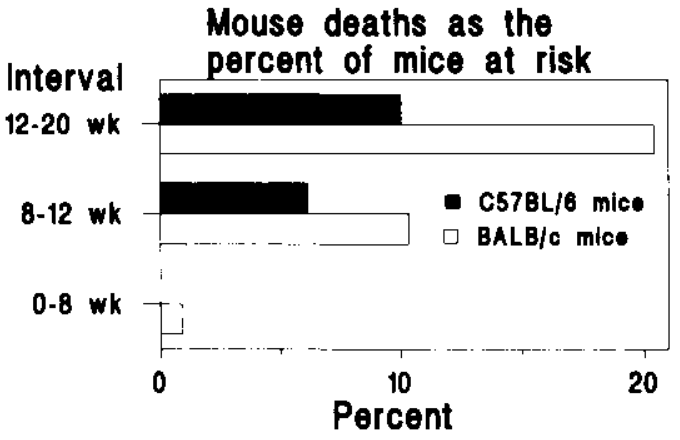

FIGURE 1. Deaths of infected mice as a percentage of mice at risk during each of the intervals between times at which mice were killed (Experiment 2). wk $=$ week.

\section{RESULTS}

The number of worm pairs recovered was proportional to the number of cercariae injected, as revealed by regression analysis of the eightweek data, averaging about seven worm pairs per mouse at eight weeks and generally declining thereafter (Figure 1).

\section{Death of worms}

In the first experiment, $1.5 \%$ of the worms were found in the lungs in 44 B6 mice examined 21 weeks after infection. The lungs of BALB mice contained $2.5 \%$ of the worms at 16 weeks, $7.1 \%$ at 20 weeks, and $3.4 \%$ at 26 weeks. Approximately half of the worms in the lungs were

TABLE 1

Worms identified in the lungs expressed as the percent of worms recovered by portal perfision, experiment 2

\begin{tabular}{|c|c|c|c|c|c|c|}
\hline \multirow[b]{2}{*}{$\begin{array}{l}\text { Mouse } \\
\text { strain }\end{array}$} & \multirow[b]{2}{*}{ Weeks } & \multirow[b]{2}{*}{$\begin{array}{l}\text { No. of } \\
\text { mice }\end{array}$} & \multicolumn{2}{|c|}{$\begin{array}{l}\text { Worms in the lungs as } \\
\text { a } \% \text { of portal woms }\end{array}$} & \multirow{2}{*}{$\begin{array}{c}\text { Estimated worm } \\
\text { pairs lost by } \\
\text { death of mice }\end{array}$} & \multirow{2}{*}{$\begin{array}{c}\text { Loss of wom } \\
\text { pairs estimated } \\
\text { by calculation } \\
\text { from original } \\
\text { worm numbers } \\
\text { \%o of } \\
\text { portal worms }\end{array}$} \\
\hline & & & $\begin{array}{l}\text { Live } \\
\text { worms }\end{array}$ & $\begin{array}{c}\text { Dead } \\
\text { worms* }\end{array}$ & & \\
\hline B $6 \div$ & 8 & 29 & 0 & 0 & 0 & NA\$ \\
\hline B6 & 12 & 27 & 2.1 & 0.6 & 3.8 & 14 \\
\hline B6 & 20 & 48 & 3.1 & 0.7 & 1.2 & 19 \\
\hline BALB & 8 & 29 & 3.4 & 0 & 1.5 & NA§ \\
\hline BALB & 12 & 29 & 6.2 & 7.3 & 18.7 & 24 \\
\hline BALB & 20 & 39 & 3.0 & 6.1 & 21.3 & 34 \\
\hline
\end{tabular}

* The number of worms lost to the lungs is probably an underestimate, particularly in chronically infected mice, because worms may be resorbed in time and mice that died are likely to have had more worms in the lungs than mice that survived.

+ Calculated as $(\mathrm{A}-\mathrm{B}) \times \mathrm{Ndead} \times 100 /(\mathrm{B} \times \mathrm{Nrisk})$, where $\mathrm{A}$ : 2 the mean number of worm pairs calculated for mice that died, $\mathrm{B}=$ the mean number of worm pairs in mice killed at the time interval in question. Ndead $=$ the number of mice that died, and Nrisk $=$ the number of mice at risk.

$\ddagger$ In B6 (C57B1/6) mice, $80 \%$ of woms in the lungs were found in the most heavily infected group, i.e., that exposed to 120 cercarieae. In BALB mice, all exposure groups were cqually affected.

$\$$ Not applicable because the number of worm pairs recovered at this time was used as the basefine figure to calculate subsequent worm loss. 

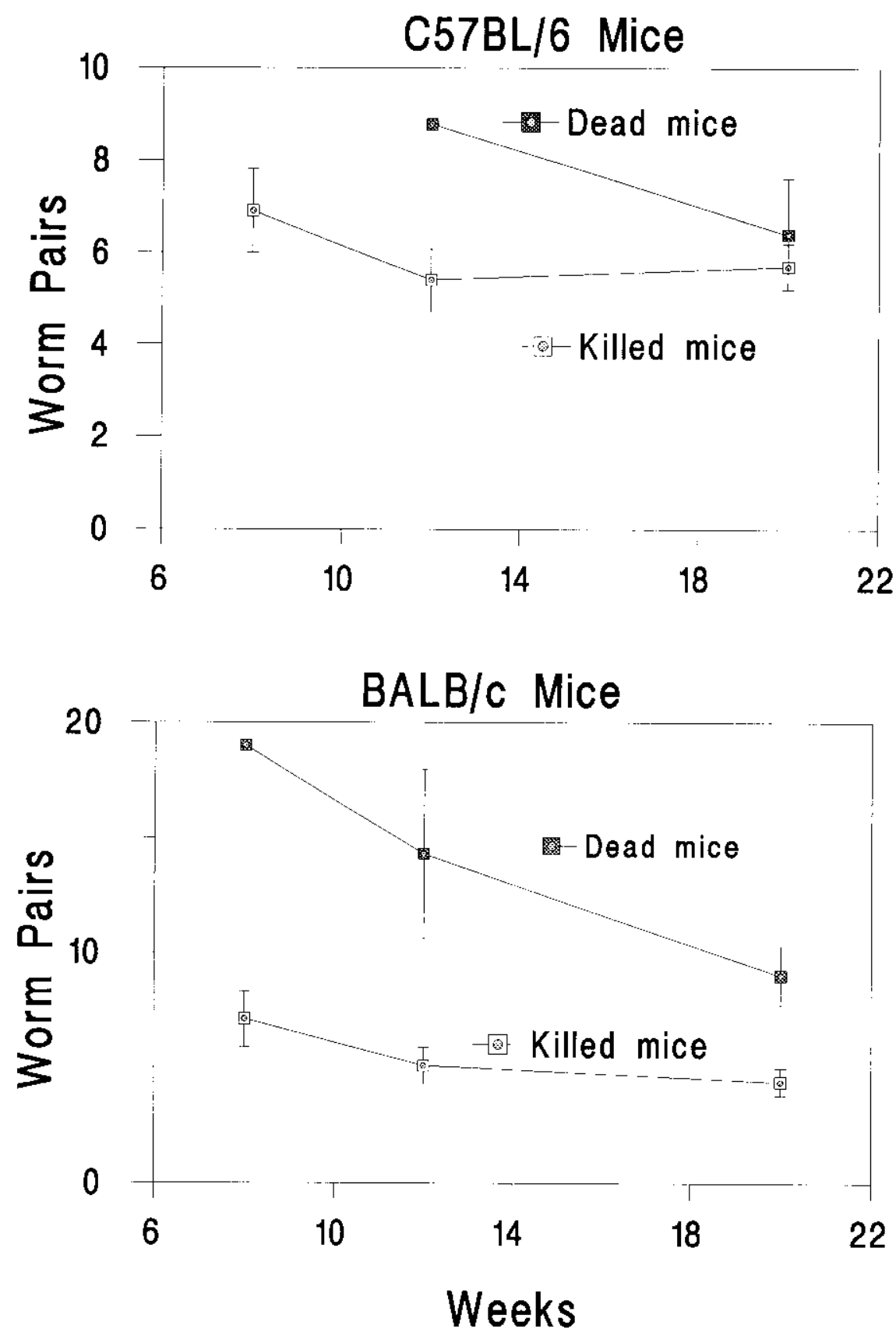

FIGURE 2. Number of worm pairs recovered during the course of Experiment 2 and the number of worm pairs calculated to be present in mice that died. The difference between worm pairs in mice killed and calculated worm pairs for mice that died is significant $(P<0.01$, by $t$-test) for BALB mice at 12 and 20 weeks. Bars show the SEM.

dead. Portal-systemic collaterals were much larger in infected BALB mice than in infected B6 mice.

A higher proportion of worms were found in the lungs in the second experiment, in which all lungs were crushed, and a maximum of $3.8 \%$ of the worms were found in the lungs in $\mathrm{B} 6$ mice at 20 weeks and a maximum of $13.5 \%$ were 
found in BALB mice at the 12th week of infection (Table 1). About half of the worms in the lungs were dead.

Worms were not found in crushed liver specimens that included about half of the liver, or in histologic sections that included most of the remaining liver.

\section{Death of mice}

Hemorrhage into the intestines was the cause of death in almost all mice and no cause of death was identified in the remainder. Deaths began during the eighth week of infection and were most common in BALB mice (Figure 1). The number of worm pairs in mice that died, estimated from the number of eggs in their livers, was greater than the number of worm pairs found in surviving mice (Figure 2). The relative effects on worm burden of the death of mice and the shunting of worms to the lungs are shown in Table 1. No uninfected mice died.

\section{Hepatic atrophy and regeneration}

Many mice examined 20 or more weeks after infection showed atrophy of the left lobe of the liver, normally the largest lobe, and of portions of other lobes. The atrophic liver was firm and darkly pigmented. The remainder of the liver in these mice was lightly pigmented, relatively soft and enlarged, i.e., regenerating. When these changes were evident, we attempted to use equal proportions of regenerated and atrophic liver for determination of collagen and egg numbers and for histology, and in one group of 14 B6 mice infected for 21 weeks, we determined egg numbers and collagen separately for atrophic and regenerated portions of the liver. Hepatic collagen and egg numbers were both significantly higher in the atrophic than in the regenerated portions of liver, but the changes were similar in magnitude and the amount of collagen per 10,000 eggs was the same (Figure 3 ). The volume of circumoval granulomas was slightly greater in atrophic than in regenerated liver.

\section{Hepatic fibrosis}

Most fibrous tissue was confined to the granulomas. The diameter of newly formed granulomas i.e., those containing a mature miracidium, decreased gradually with time (Figure 4).

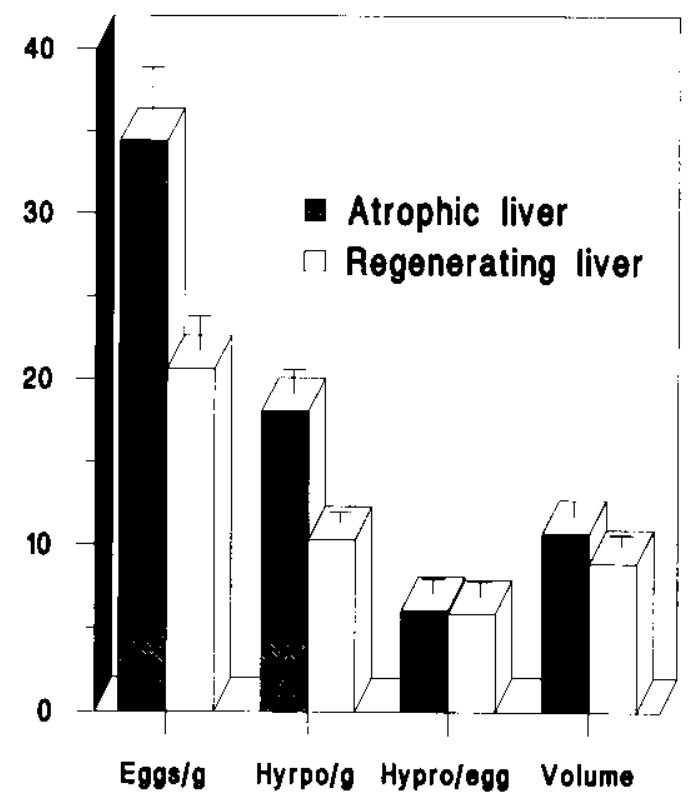

Figure. 3. Parasitologic and pathologic findings in atrophic versus regenerating portions of the liver in B6 mice in Experiment 1. Eggs (thousands of eggs/g of liver) and collagen in $\mu$ moles of hydroxyproline/g (Hypro/g) were concentrated in the atrophic liver, but hydroxyproline in $\mu$ moles per 10,000 liver eggs (hypro/egg) did not change. The small difference in granuloma volume (plotted in $\mathrm{mm}^{3} \times 10^{3}$ ) is significant $(P<0.05$, by paired $t$-test). Bars show the SEM.

Granulomas around single eggs were of comparable size in the two mouse strains, while granulomas around multiple eggs were significantly larger in B6 mice at eight and 12 weeks after infection. Hepatic collagen increased steadily as the duration of infection increased and was about 2-3 times greater than in normal liver eight weeks after infection and about 10 times greater than normal at 12 and 20 weeks after infection (Figure 5). Hepatic fibrosis per 10,000 eggs increased between eight and 12 weeks but was variable thereafter (Figure 5), reflecting the complex interaction between deposition and resorption of collagen and deposition and resorption of eggs. Liver fibrosis increased roughly in proportion to the number of worm pairs recovered. However, fibrosis normalized for egg numbers, i.e. fibrosis per 10,000 hepatic eggs, decreased significantly with increasing infection intensity in both mouse strains and at each interval studied (data not shown). 


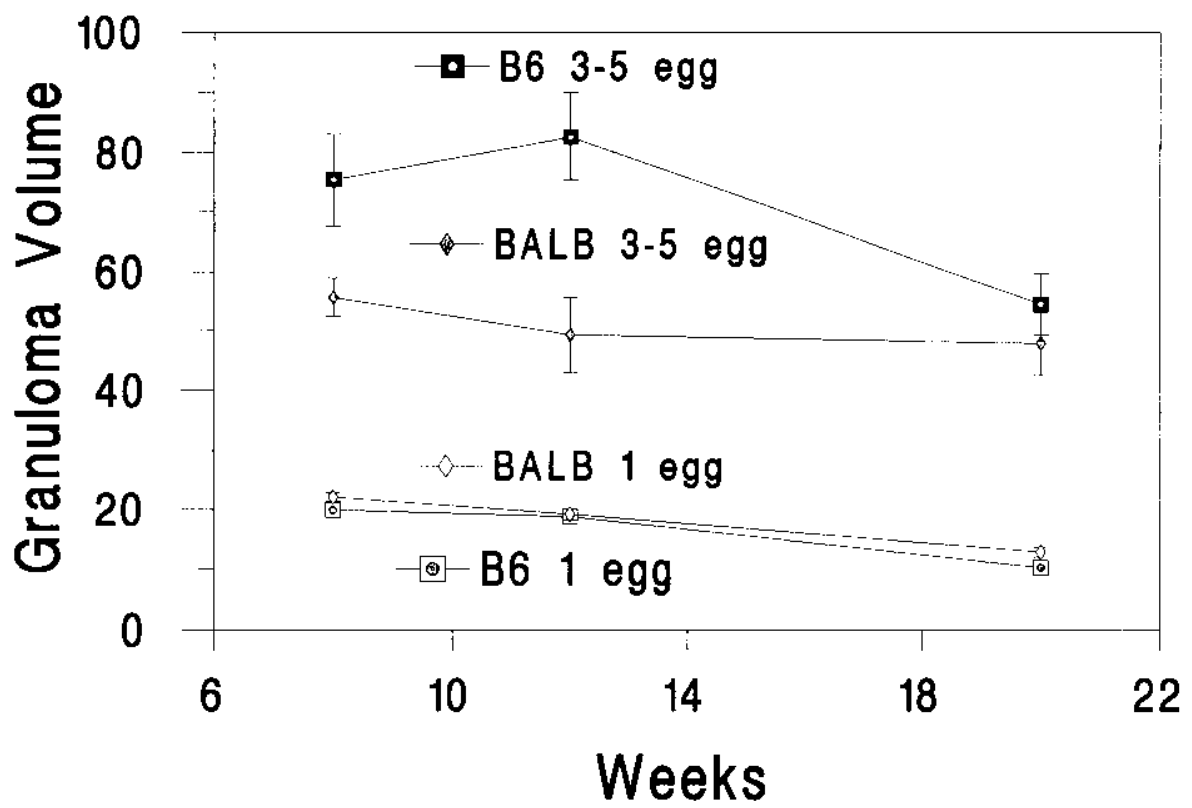

FIGURE 4. Volume of granulomas around single eggs and around clusters of 3-5 eggs for B6 and BALB mice at various intervals after infection in Experiment 2. The B6 mice formed larger granulomas around egg clusters at eight and 12 weeks than did BALB mice $(P<0.05$ and $<0.01$, respectively, by $t$-test $)$. Bars show the SEM.

Effects of infection intensity on other parasitologic and pathologic parameters

The number of eggs per worm pair in the tissues and in the feces tended to decrease as infection intensity increased, as did granuloma volume and the percentage of eggs in the liver, but the effects were neither dramatic nor consistent (Table 2).

\section{Eggs in the tissues and in the feces}

The number of eggs per worm pair in the tissues increased with time in a nearly linear fashion, while the number of eggs per worm pair in the feces decreased by half between the eighth and 20th weeks of infection in both strains of mice (Figure 6). The predicted rate of egg laying during this period diminished in proportion to the decrease of eggs passed in the feces (Figure 7). The number of tissue eggs per worm pair was greater in B6 mice than in BALB mice at 12 and 20 weeks after infection $(P<0.05$, by analysis of covariance). We have not corrected the number of eggs per worm pair in the tissues for the worm pairs lost to the lungs. The number of eggs in the lungs per worm pair was much greater in BALB mice than in B6 mice (Figure 8 and Table $3)$.

The number of eggs in the tissues and feces at any given time was related to the number of worm pairs, but the relationship between intensity of infection and fecal eggs was complex. The number of eggs per worm pair in the feces varied with the number of worm pairs in B6 mice at 12 weeks and in BALB mice at 20 weeks in Experiment 2 (Table 2). The number of eggs per worm pair passed in the feces was greater in B6 mice than in BALB mice at eight and at 12 weeks (Figure 6; $P<0.005$ at eight weeks and $<0.05$ at 12 weeks, by analysis of covariance).

The distribution of granulomas in the lungs was diffuse and bilateral, suggesting that the eggs were not laid by worms in the intrapulmonary arterial branches but were shunted there from the portal system or laid by worms located in portal-systemic collaterals.

\section{DISCUSSION}

Death of the most heavily infected mice and shunting of worms to the lungs each contributed 

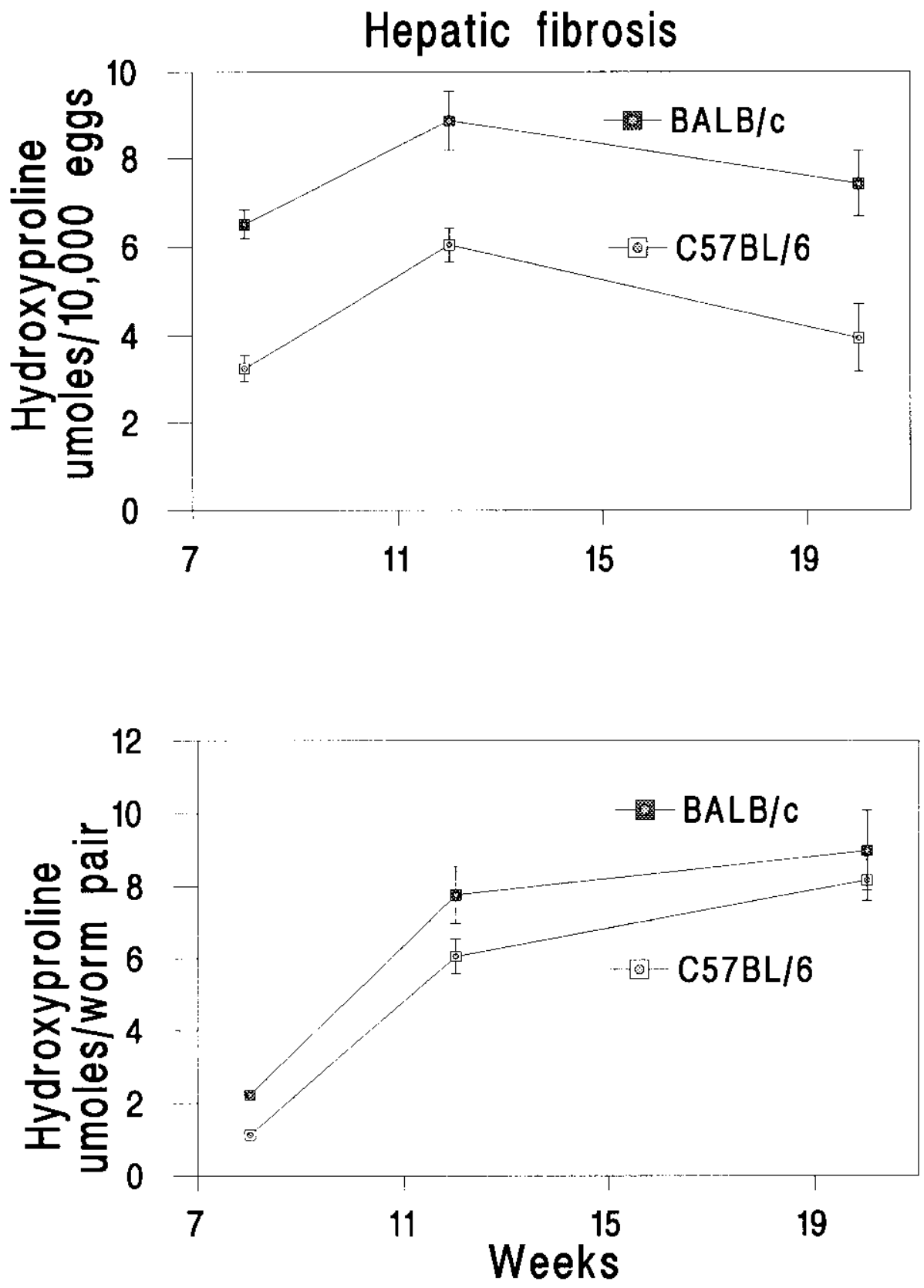

FlGure 5. Hepatic fibrosis per worm pair or per 10,000 eggs for both strains of mice (Experiment 2). The hydroxyproline content of the normal livers has been subtracted $(2.36$ ( $\mu$ moles/liver and $2.09 \mu$ moles/liver in B6 and BALB mice, respectively). The difference in hydroxyproline per 10,000 eggs in the two mouse strains is significant at each time point by analysis of covariance $(P<0.0001$ at eight and 20 weeks and $P<0.05$ at 12 weeks). Bars show the SEM. 
TABLE 2

Slopes of the regression of the logarithm (base e) of various variables on the logarithm of worm pairs*

\begin{tabular}{|c|c|c|c|c|}
\hline Weeks & $\begin{array}{l}\text { Number } \\
\text { and sex } \\
\text { of mice }\end{array}$ & $\begin{array}{c}\text { Tissuc } \\
\text { eggs per } \\
\text { worm pair }\end{array}$ & $\begin{array}{l}\text { Granulomia } \\
\text { volume }\end{array}$ & $\begin{array}{c}\text { Fecal } \\
\text { eggs per } \\
\text { worm pair }\end{array}$ \\
\hline \multicolumn{5}{|c|}{ Experiment $2, \mathrm{C} 57 \mathrm{Bl} / 6 \mathrm{mice}$} \\
\hline 8 & $29 \mathrm{~F}$ & $+0.42+$ & +0.05 & +0.30 \\
\hline 12 & $27 \mathrm{~F}$ & $-0.19+$ & $+0.15 \div$ & -0.47 \\
\hline 20 & $48 \mathrm{~F}$ & -0.02 & $-0.17 \div$ & $-0.73 \mp$ \\
\hline \multicolumn{5}{|c|}{ Experiment, 2 BALB mice } \\
\hline 8 & $29 \mathrm{~F}$ & +0.003 & 0 & -0.17 \\
\hline 12 & $29 \mathrm{~F}$ & $-0.20+$ & -0.001 & $-0.63 \ddagger$ \\
\hline 20 & $29 \mathrm{~F}$ & $-0.19+$ & -0.12 & -0.42 \\
\hline \multicolumn{5}{|c|}{ Experiment $1, \mathrm{C} 57 \mathrm{Bl} / 6$ mice } \\
\hline 21 & $18 \mathrm{~F}$ & +0.07 & -0.20 & -0.33 \\
\hline 21 & $26 \mathrm{M}$ & -0.03 & -0.04 & -0.32 \\
\hline \multicolumn{5}{|c|}{ Experiment 1, BALB mice } \\
\hline 16 & $22 \mathrm{M}$ & -0.29 & +0.16 & ND \\
\hline 20 & $55 \mathrm{M}$ & -0.24 丰 & +0.14 & -0.07 \\
\hline 26 & $23 \mathrm{M}$ & -0.28 & $-0.45 \ddagger$ & ND \\
\hline
\end{tabular}

to the reduced average number of worm pairs recovered from the mesenteric circulation of the surviving mice. We also calculated the decrease in portal worms using the number of worm pairs recovered eight weeks after infection as the index of initial infection intensity. The decrease in worm numbers thus calculated was equal to the sum of worm attrition to the lungs and through death of mice for BALB mice, but in B6 mice calculating worm loss from the original worm burden appeared to overestimate worm loss (Table 1). We have greater confidence in our ability to locate dead worms and to calculate worm burden from liver eggs than we do in projection from the initial worm burden. However, it is conceivable that B6 mice rapidly destroy dead worms and that we did not find them for this reason.

The magnitude of loss of worms was greater in BALB than in B6 mice. Dislocation of worms to the lungs appeared to be related to the degree of portal-systemic shunting. Portal-systemic collateral veins were larger in BALB than in B6 mice and the number of eggs in the lungs also reflects greater shunting. No dead worms were noted in the livers of any mice, in spite of an intensive search for them. Thus, it would seem that the worms are first shunted to the lungs and then die there, and that they are not dying of old age or primarily from host immune attack, although one could argue that damaged worms are shunted preferentially to the lungs. Kloetzel found dead worms in the livers of half of the mice in his studies with infections of more than 20 weeks, ${ }^{3}$ presumably reflecting a different host-parasite relationship than in our mice, of which 26 BALB mice were examined 26 weeks after infection. Similarly, Maloney and others found small numbers of dead S. mansoni in the portal blood of $\mathrm{A} / \mathrm{J}$ strain mice as early as eight and 10 weeks after infection, ${ }^{11}$ and Lenzi and others noted dead worms in the livers of Swiss mice 60 days after infection. ${ }^{12}$

Greater host mortality in more heavily infected mice has been noted by numerous investigators. ${ }^{3,4,1,3}$

We consider the rate of death of worms in our mice to be irrelevant to infections in most humans because portal-systemic collaterals do not develop rapidly in humans and because considerably less than $10 \%$ of infected humans are likely to have significant collaterals, even in heavily endemic areas. ${ }^{14}$ Death of more heavily infected persons is also unlikely to have an appreciable effect on worm numbers since a small proportion of infected humans die from schistosomal disease.

We estimate daily egg production by the worms to average 436 eggs per worm pair per day in B6 mice and 315 in BALB mice 8-12 weeks after infection. The rate of egg laying decreased about $15 \%$ between the 12th and 20 th weeks of infection in both strains of mice. The passage of eggs in the feces decreased proportionally. Since worm fecundity was calculated from mean values at different time periods, we did not evaluate apparent differences in fecundity statistically but the standard errors of the difference of the means were large for both tissue and fecal eggs (Figure 7). Much more marked decreases in egg passage in the feces with increasing duration of infection were reported by $\mathrm{Kloetzel}^{3}$ and by Sithithaworn, ${ }^{4}$ while our own previous experience has shown no decrease in egg excretion in $S$. mansoni-infected mice. ${ }^{6.15}$ The use of different schistosome strains and different murine hosts may explain these differences, but the only evident difference from one of our previous studies, in which B6 mice with a single worm pair were studied, is the intensity of infection. ${ }^{\circ}$ Jones and others found 

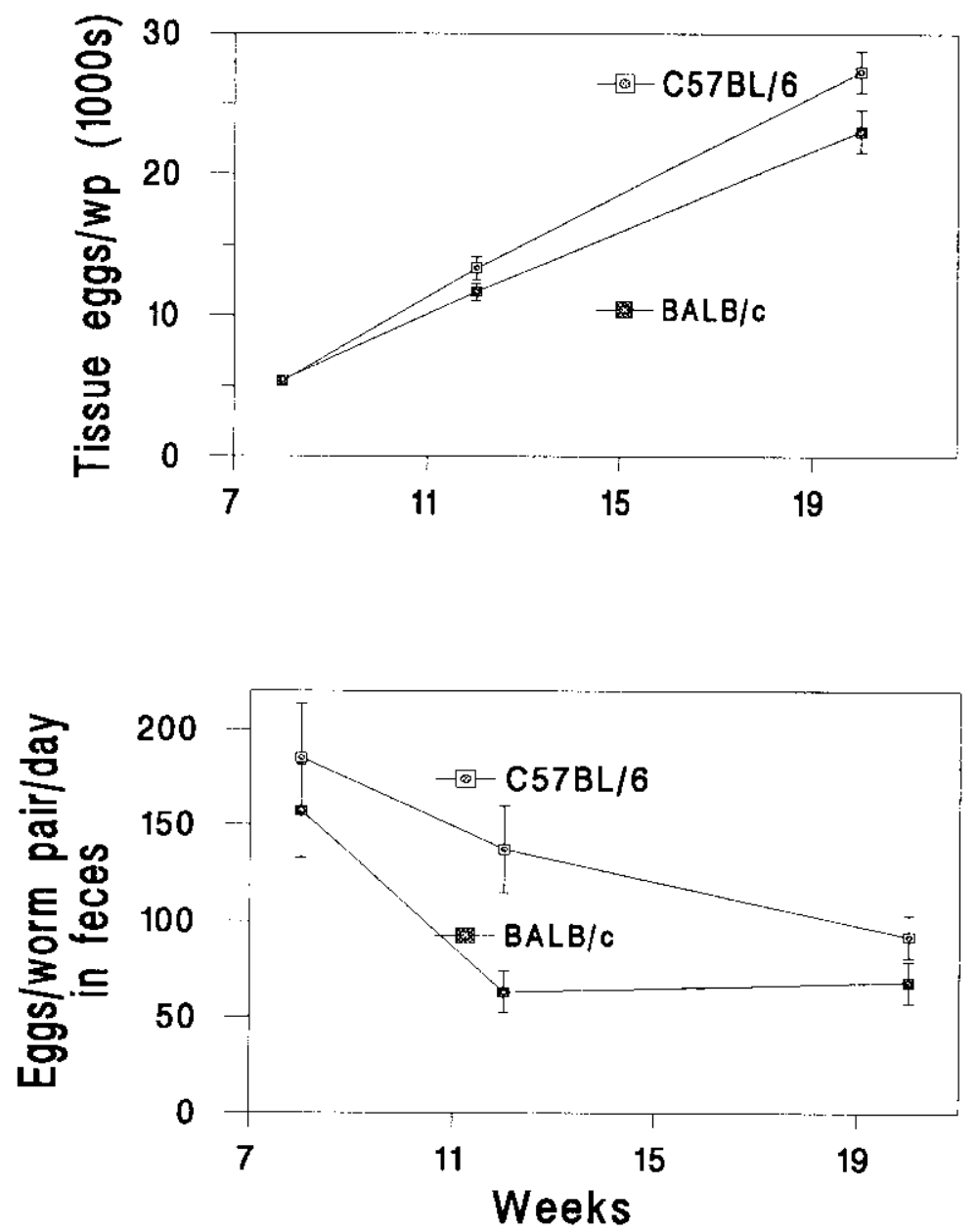

FIGURE 6. Cumulative numbers of tissue eggs per worm pair (liver + gut + lung eggs) and fecal cggs per day per worm pair for the two mouse strains (Experiment 2). The decrease in fecal eggs per worm pair was significant in BALB mice $(P<0.01)$ by analysis of covariance, but could not be evaluated in B6 mice because the slopes of regressions of fecal eggs on worm pairs differed significantly. The B6 mice passed more eggs per worm pair in the feces than did BALB mice at eight and 12 weeks $(P<0.01$ and $<0.05$, respectively). Bars show the SEM. wp = worm pair.

more eggs/g of feces/worm pair in NIH mice than in CBA mice. ${ }^{13}$

A decrease in fecal eggs per worm pair with time was seen in rhesus monkeys with heavy $S$. mansoni infections and a less marked and more gradual change was described in grivet monkeys. ${ }^{6.16}$ In both of these hosts, decreased egg passage in the feces also paralleled diminished egg laying by the worms, i.e., the number of eggs per worm pair in the tissues also decreased. However, passage of eggs in the feces is clearly not always a good indication of deposition of eggs in the tissues. ${ }^{6}$
We have not corrected our estimates for the mice for the effects of egg destruction, an effect that we judge to be slight. ${ }^{6}$ Whether such changes in passage of eggs in the feces are relevant for infected humans is uncertain, although the number of eggs per worm pair found in the feces of $S$. mansoni-infected cadavers was unrelated to age and thus presumably to duration of infection. ${ }^{17.18}$ Probably most of those infections in humans were already chronic, at which point temporal changes may not be marked.

Increasing intensity of infection was uniformly associated with a decrease in hepatic fibrosis 


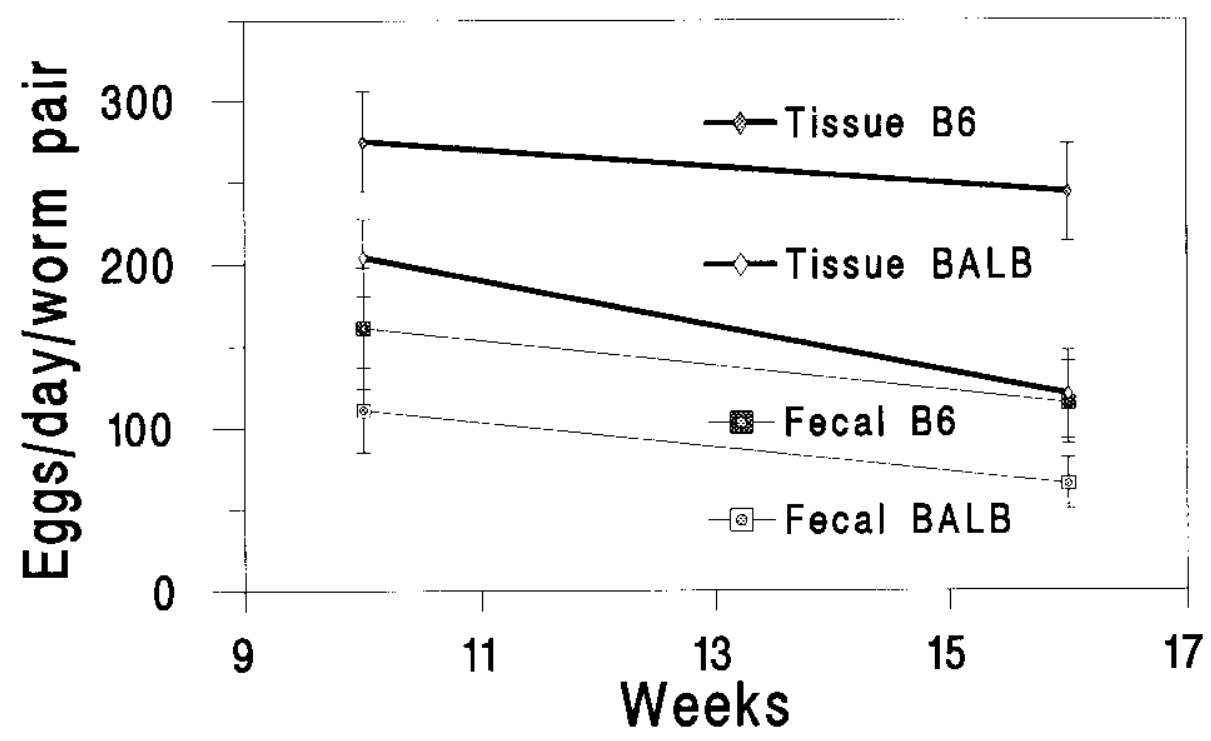

FIGURE 7. Estimated number of eggs per day laid by Schistosoma mansoni worm pairs in the two strains of mice (Experiment 2). Fecal eggs per day are the average of eight- and 12-week determinations for the first timepoint and the average of $12-$ and 20 -week values for the second timepoint. Tissue eggs per day were calculated from the difference in eggs per worm pair in the tissues between these same time points, and the total eggs per day is the sum of fecal and tissue eggs. Bars show one standard error of the difference of the means.

per 10,000 eggs in the present and previous 6,10 experiments. Fewer eggs per worm pair were generally passed in the feces in more heavily infected mice while the effects on tissue eggs were inconsistent and seldom significant (Table 2). A much more marked density-dependent decrease in egg passage in the feces has been noted in infected mice by Sithithaworn, ${ }^{4}$ and a more moderate effect was documented by Jones and others. ${ }^{13}$ The number of eggs/worm pair in the tissues of infected humans decreased somewhat with increasing intensity of infection, ${ }^{19}$ but the number of eggs/worm pair passed in the feces did not change significantly with infection intensity, ${ }^{17}$ except if patients in whom no fecal eggs were found were excluded from the analysis. ${ }^{20}$

Schistosoma mansoni eggs may be destroyed more rapidly in the lungs than in the liver and gut, ${ }^{21}$ and this might have a significant effect in BALB mice. We have also not corrected for the

TABLE 3

Parasitologic findings and granuloma volume in C57BL/6 and BALB mice during the course of Schistosoma mansoni infection*

\begin{tabular}{|c|c|c|c|c|c|c|}
\hline \multirow[b]{2}{*}{ Weeks } & \multirow{2}{*}{$\begin{array}{l}\text { Number and } \\
\text { sex of mice }\end{array}$} & \multicolumn{2}{|c|}{$\begin{array}{c}\text { Tissue eggs per } \\
\text { worm pair }(1,000 \mathrm{~s})\end{array}$} & \multirow{2}{*}{$\begin{array}{l}\text { Percent } \\
\text { cggs in } \\
\text { liver }\end{array}$} & \multirow{2}{*}{$\begin{array}{c}\text { Granuloma } \\
\text { volume }\end{array}$} & \multirow{2}{*}{$\begin{array}{l}\text { Fecal eggs } \\
\text { per worm }\end{array}$} \\
\hline & & Liver and gut & Lungs & & & \\
\hline \multicolumn{7}{|c|}{ Experiment $1, \mathrm{C} 57 \mathrm{Bl} / 6$ mice } \\
\hline 21 & $18 \mathrm{~F}$ & $23.0 \pm 1.8$ & 0.3 & $81 \pm 2$ & $9 \pm 1$ & $75 \pm 16(18)$ \\
\hline 21 & $26 \mathrm{M}$ & $23.0 \pm 2.5$ & 0.3 & $91 \pm 1$ & $10 \pm 1$ & $44 \pm 7(26) \dagger$ \\
\hline \multicolumn{7}{|c|}{ Experiment I, BALB mice } \\
\hline 16 & $22 \mathrm{M}$ & $18.7 \pm 2.0$ & 0.1 & $84 \pm 2$ & $13 \pm 1$ & ND \\
\hline 20 & $55 \mathrm{M}$ & $20.6 \pm 1.8$ & 1.7 & $81 \pm 2$ & $16 \pm 1$ & $36 \pm 5(31)$ \\
\hline 26 & $23 \mathrm{M}$ & $26.2 \pm 2.3$ & 3.0 & $88 \pm 2$ & $11 \pm 1$ & ND \\
\hline
\end{tabular}

* Values are the mean \pm SFM. Values in parentheses are the no. of mice in which feces were examined. ND = not done.

$+P=0.05$ versus female mice, by analysis of covariance. However on another occasion we noted significantly higher egg excretion 12 weeks after infection in C57B1/10.M male mice than in females (Cheever AW, unpublished data). 


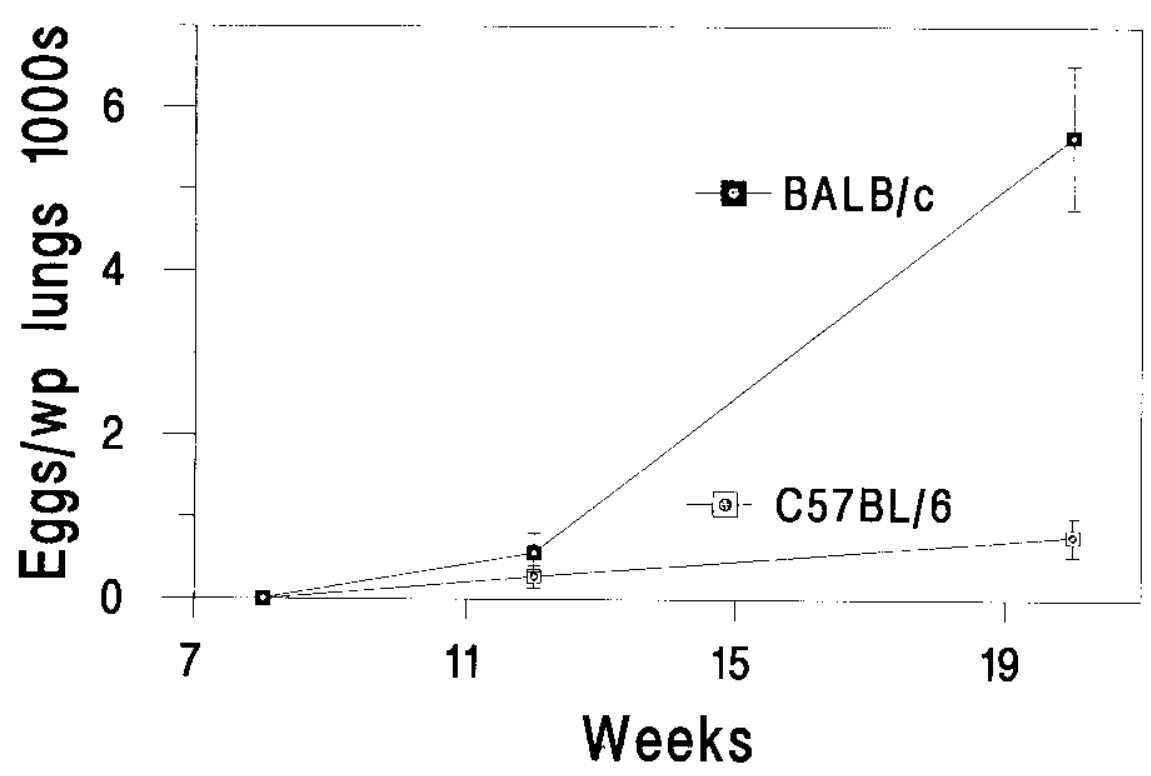

Figurf 8. Eggs per worm pair in the lungs of BALB and B6 mice in Experiment 2. Bars show the SEM. wp $=$ worm pair.

worm pairs lost to the lungs and have divided the total tissue eggs by worm pairs remaining in the portal system to calculate tissue eggs per worm pair. Such a correction would have a minimal effect in analysis of the data from B6 mice and only a small effect for BALB mice, but would further decrease the number of eggs per worm pair in BALB mice compared with B6 mice.

The reasons for hepatic atrophy and its localization primarily in the large left lobe of the liver are unknown. The left lobe of the human liver is that most enlarged in patients with clinical hepatosplenic schistosomiasis mansoni, but eggs are not concentrated in the left lobe. ${ }^{17}$ In mice, we did not find that eggs were concentrated in the small suprarenal lobe compared with the remainder of the liver eight weeks after infection, ${ }^{22}$ but no further studies were done. Streamlining of portal flow from the superior and inferior mesenteric veins into different portions of the liver would affect egg distribution, but microspheres injected into the ileocecal and splenic veins of rats were uniformly distributed in the livers. ${ }^{23}$

It is clear that hepatic atrophy and regeneration will influence the estimates of hepatic eggs and fibrosis. One would doubtless be well-advised to mix samples from the various lobes be- fore gross changes are evident. We were surprised that hepatic fibrosis per egg remained similar in atrophic and regenerated lobes because the changes are mainly chronic in the atrophic tissue and largely recent in the regenerated liver.

In summary, worms were shunted from the portal circulation to the lungs of the mice in the present study as portal-systemic collaterals developed, but we saw no signs of death of worms in the portal system. However, we attribute most of the decrease in worm burden in chronically infected mice to the premature death of more heavily infected mice in our experiments. Loss of worms by either mechanism varied with intensity of infection and the strain of mouse used. The fecundity of $S$. mansoni worm pairs decreased slightly in more chronically infected mice, but the rate of deposition of eggs in the tissues and passage of eggs in the feces paralleled each other.

Acknowledgments: We are grateful to the animal care staff of the National Institute of Allergy and Infectious Diseases, National Institutes of Health for both excellent animal husbandry and for assistance in the collection of mice that died.

Authors' addresses: Allen W. Cheever, Subrato Deb, and Rodney H. Duvall, Laboratory of Parasitic Diseases, National Institute of Allergy and Infectious Dis- 
eases, National Institutes of Health, Bethesda, MD 28092. James E. Mosimann, National Institutes of Health, Bethesda, MD 20892. Erik A. Cheever, Department of Engineering, Swarthmore College, Swarthmore, PA 19081.

\section{RFFERENCES}

1. Crombie JA, Anderson RM, 1985. Population dynamics of Schistosoma mansoni in mice repeatedly exposed to infection. Nature 315 : 491493.

2. Roushdy MZ, Frandsen F, 1983. Interaction of different loads of Schistosoma mansoni in mice. J Egypt Soc Parasitol 13: 253-260.

3. Kloetzel K, 1967. Egg and pigment production in Schistosoma mansoni infections of the white mouse. Am J Trop Med Hyg 16: 293-299.

4. Anderson RM, May RM, 1991. Infectious Diseases of Humans. Dynamics and Control. Oxford: Oxford University Press.

5. Stirewalt MA, Uy A, 1969. Schistosoma mansoni: cercarial penetration and schistosomule collection in an in vitro system. Exp Parasitol 26: $17-28$.

6. Cheever AW, Macedonia JG, Mosimann JE, Cheever EA, 1994. Kinetics of egg production and egg excretion by Schistosoma mansoni and $\mathrm{S}$. japonicum in mice infected with a single pair of worms. Am J Trop Med Hyg 50: 281-295.

7. Duvall RH, DeWitt WB, 1967. An improved perfusion technique for recovering adult schistosomes from laboratory animals. Am J Trop Med Hyg 16: 483-486.

8. Prockop DJ, Udenfriend S, 1960. A specific method for the analysis of hydroxyproline in tissues and urine. Anal Biochem 1: 228-239.

9. Bergman I, Loxley R, 1963. Two improved and simplified methods for the spectrophotometric determination of hydroxyproline. Anal Chem 35: $1961-1965$.

10. Cheever AW, 1986. The intensity of experimental schistosome infections modulates hepatic pathology. Am J Trop Med Hyg 35: 124-133.

11. Maloney MD, Coles GC, Semprevivo LH, 1989. Attrition of adult Schistosoma mansoni in $\mathrm{A} / \mathrm{J}$ mice. Proc Helminthol Soc Wash 56: 87-90.
12. I enzi HL, Sobral ACL, Lenzi JA, 1987. In vivo kinetics of eosinophils and mast cells in experimental murine schistosomiasis. Mem Inst $O$ swaldo Cruz 82 (suppl 4): 67-76.

13. Jones JT, Breeze P, Kusel JR, 1989. Schistosome fecundity: influence of host genotype and intensity of infection. Int $J$ Parasitol 19: 769-777.

14. Costa MFFdeL, Rocha RS, Magalhaes MHdeA, Katz N, 1985. A clinico-epidemiological survey of schistosomiasis mansoni in a hyperendemic area in Minas Gerais state (Comercinho, Brazil). I. Differences in the manifestations of schistosomiasis in the town centre and in the environs. Trans $R$ Soc Trop Med Hyg 79: 539-545.

15. Cheever AW, 1969. Quantitative comparison of the intensity of Schistosoma mansoni infection in man and experimental animals. Trans $R$ Soc: Trop Med Hyg 63: 781-795.

16. Cheever AW, Duvall RH, 1968. Single and repeated infections of grivet monkeys with Schistosoma mansoni: parasitological and pathological observations over a 31-month period. Am J Trop Med Hyg 23: 884-894.

17. Cheever AW, 1968. A quantitative post mortem study of schistosomiasis mansoni in man. Am J Trop Med Hyg 17: 38-64.

18. Cheever AW, Kamel IA, Elwi AM, Mosimann JE, Danner R, 1977. Schistosoma mansoni and S. haematobium infections in Egypt. II. Quantitative parasitological findings at necropsy. Am $J$ Trop Med Hyg 26: 702-716.

19. Cheever AW, 1986. Density-dependent fecundity in Schistosoma mansoni infections in man: a reply. Trans $R$ Soc Trop Med Hyg 80: 991-992.

20. Medley G, Anderson RM, 1986. Density-dependent fecundity in Schistosoma mansoni infections in man. Trans $R$ Soc Trop Med Hyg 79: 532-534.

21. Almedia MAC, Andrade ZA, 1983. Effect of chemotherapy on experimental pulmonary schistosomiasis. Am J Trop Med Hyg 32: 1049-1054.

22. Cheever AW, Warren KS, 1964. Hepatic blood flow in mice with acute hepato-splenic schistosomiasis mansoni. Trans $R$ Soc Trop Med Hyg 58: $406-412$.

23. Blei AT, O'Reilly DJ, Gottstein J, Hauck WW, Zimmer M, 1984. Distribution of portal blood flow in the liver of the rat: a microsphere study. J Lab Clin Med 104: 404413. 